\title{
PENERAPAN PEMBELAJARAN MATEMATIKA REALISTIK DALAM KELOMPOK KOOPERATIF UNTUK MENINGKATKAN HASIL BELAJAR MATEMATIKA MAHASISWA S1 PGSD TAHUN AKADEMIK 2013
}

\author{
${ }^{1}$ Hapipi, ${ }^{2}$ Syahrul Azmi, ${ }^{3}$ Aos Santosa H \\ ${ }^{1}$ Dosen Program Studi Pendidikan Matematika, Jurusan PMIPA FKIP Universitas Mataram \\ (JI. Majapahit 62 Mataram, Email : hapipiunram@gmail.com) \\ ${ }^{2,3}$ Dosen Program Studi Pendidikan Matematika, Jurusan PMIPA FKIP Universitas Mataram
}

\begin{abstract}
ABSTRAK
Penelitian ini dimaksudkan untuk meningkatkan hasil belajar mahasiswa pada matakuliah Matematika Dasar dengan melakukan perbaikan kualitas proses pembelajaran. Perbaikan kualitas proses ini dilakukan dengan menerapkan pembelajaran berbasis realistik dalam kelompok kooperatif. Penelitian ini adalah penelitian tindakan kelas (PTK) yang dilaksanakan dalam dua siklus. Hasil penelitian menunjukkan bahwa terjadi peningkatan hasil belajar mahasiswa pada materi persamaan/pertidaksamaan linear dan persamaan/pertidaksamaan kuadrat. Ketuntasan klasikal mencapai $61 \%$ pada siklus I, sedangkan pada siklus II mencapai $88 \%$.
\end{abstract}

Kata Kunci: Hasil Belajar, Pembelajaran Matematika Realistik

\begin{abstract}
The aim of this study is to improve student achievment on learning mathematic through improving quality of learning process. The improvement of quality process is carried out by applying realistic mathematic education (RME) pinciples in cooperative groups. This study is a classroom action research, which was conducted in two cycles. The results showed that an increase in student achievments on topic linear equation and inequalities, as well quadratic equations and inequalities. This result confirmed that apllying RME is important on learning process.
\end{abstract}

Keywords: Student achievments, RME

\section{PENDAHULUAN}

Matematika merupakan salah satu materi wajib yang diampu mahasiswa S1 PGSD. Secara umum, muatan materi pokok yang menjadi bahasan dalam kuliah matematika S1 PGSD adalah materi-materi yang diperlukan untuk mendukung pembelajaran matematika di level sekolah dasar (SD). Tentu saja materi ini diperlukan untuk mendukung kompetensi mahasiswa sebagai calon guru SD. Sedikitnya ada empat matakuliah matematika yang menjadi matakuliah wajib S1 PGSD, yaitu Matematika Dasar, Pendidikan Matematika Kelas Rendah, Pendidikan Matematika Kelas Tinggi, dan Matematika Kontemporer.

Namun demikian, prestasi belajar mahasiswa pada matakuliah matematika, yang salah satunya ditunjukkan oleh perolahan hasil belajar masih belum bisa disebut memuaskan. Berdasarkan pengalaman selama tiga tahun mengampu matakuliah matematika dasar, diketahui bahwa persentase jumlah mahasiswa yang memperoleh nilai "D" atau "E" selau berkisar pada angka $35 \%$, sedangkan persentase mahasiswa yang mendapat nilai " $\mathrm{C}$ ", "D", atau "E" berkisar pada angka 78\%. Ini berarti jumlah mahasiswa yang berhasil memperoleh nilai bagus, "B" atau "A" masih relatif kecil.

Perolehan nilai yang belum memuaskan ini terjadi karena mahasiswa mengalami kesulitan dalam memahami materi yang terkait dengan persamaan dan pertidaksamaan, serta geometri. Mahasiswa mengalami kesulitan dalam mengkonstruksi model matematika dari persoalan yang berbentuk soal cerita, sehingga mahasiswa gagal dalam menyelesaikan permasalahan-permasalahan matematik semacam itu.

Dari pengamatan yang dilakukan diketahui bahwa kondisi ini disebabkan oleh sedikitnya tiga faktor utama, yaitu: 1) Input mahasiswa. Latar belakang mahasiswa sangatlah beragam. Ada banyak mahasiswa 
yang mempunyai pengalaman tidak terlalu menyenangkan belajar matematika sejak mereka duduk di bangku sekolah dasar. Sehingga persepsi "matematika tidak menarik" tersebut sudah terlanjur terbangun yang berdampak pada rendahnya minat belajar mahasiswa pada matematika; 2) Mahasiswa mengalami kesulitan dalam memahami simbolsimbol matematika dan menggunakannya dalam menyelesaikan masalah matematika; dan 3) Desain pembelajaran yang dipraktikkan dosen mengacu pada keyakinan bahwa mahasiswa telah berada pada level berfikir formal, sebagaimana dinyatakan Piaget, sehingga teknik penyampaian gagasananya juga dilakukan dengan teknik matematika formal (konsep matematika sudah jadi). Kombinasi dari ketiga masalah tersebut berdampak pada rendahnya prestasi belajar mahasiswa pada materi matematika.

Schoenfeld dalam Yuwono [1] menyatakan bahwa pembelajaran matematika secara konvensional (misalnya metode ceramah atau ekspositori), mengakibatkan siswa hanya menghafal dan bekerja secara prosedural dan memahami matematika tanpa penalaran. Siswa pasif mendengarkan penjelasan guru dan tidak terlibat aktif baik secara fisik (bekerja) maupun secara mental (berfikir).

Pembelajaran matematika realistik (PMR) merupakan model pembelajaran yang berangkat dari realitas empirik siswa/ mahasiswa untuk membangun konsep matematika. Basis filosofis model ini adalah bahwa "Belajar matematika sebagai aktivitas manusia". Artinya adalah pembelajaran matematika harus dilakukan dalam aktivitas matematis. Pembelajaran harus berangkat dari pengalaman nyata, atau dengan menghubungkan konsep yang akan dipelajari dengan realitas sekitar siswa/mahasiswa. Pembelajaran tidak dimulai dari konsepnya yang abstrak (deduktif).

Pendekatan pembelajaran seperti ini tentunya akan memudahkan mahasiswa dalam mengkosntruksi pemahaman mereka mengenai konsep persamaan dan pertidaksamaan. Karena sejatinya, gagasan mengenai persamaan dalam matematika berhubungan sangat dekat dengan permasalahan dalam kehidupan nyata. Pembelajaran matematika realistik akan memberikan kesempatan pada mahasiswa untuk memperoleh pemahaman dengan lebih kongkrit.

Dalam penerapannya, pembelajaran matematika realistik ini dapat pula dilaksanakan dalam desain kooperatif. Hal ini dimaksudkan agar interaksi siswa dalam belajar tinggi. Interaksi ini diperlukan agar terjadi saling dukung pemahaman antar sesama siswa.

Lie dalam Azmi [2] menyatakan bahwa model pembelajran kooperatif memiliki banyak kelebihan, antara lain: (1) meningkatkan keterampilan berkomunikasi dan meningkatkan keahlian dalam menyampaikan ide-ide yang telah dikemukakan, (2) meningkatkan kemampuan bekerjasama dan menjalin kebersamaan, (3) menumbuhkan sikap sosial, motivasi, harga diri, dan sikap positif, (4) meningkatkan proses dan hasil belajar siswa dengan prestasi akademik yang tinggi.

Oleh karena itu, untuk coba memecahkan problem yang dihadapi mahasiswa S1 PGSD dalam kuliah matematika pokok bahasan persamaan dan pertidaksamaan, akan dilakukan penelitian dengan judul "Penerapan Pembelajaran Berbasis Realistik Dalam Kelompok Kooperatif Sebagai Upaya Meningkatkan Hasil Belajar Matematika Mahasiswa S1 PGSD Tahun Akademik 2013".

\section{METODE PENELITIAN}

Penelitian ini adalah penelitian tindakan kelas (PTK). Penelitian tindakan kelas (PTK) adalah suatu penelitian yang dilakukan oleh guru atau seseorang tertentu di dalam kelas dengan tujuan untuk memperbaiki kinerja sebagai guru, sehingga hasil belajar siswa menjadi meningkat [3].

Penelitian ini dilaksanakan dalam dua siklus dengan mengikuti tahapan PTK, yaitu: perencanaan, pelaksanaan tindakan, pengamatan, dan evaluasi dan refleksi. Materi pada siklus I adalah persamaan dan pertidaksamaan linear, sedangkan materi siklus II adalah persamaan dan pertidaksamaan kuadrat. Peneletian ini dikatakan berhasil apabila minimal $85 \%$ mahasiswa memperoleh nilai minimal kategori C (56 dalam skala 100). Terjadi ketuntasan klasikal.

\section{HASIL DAN PEMBAHASAN \\ A. HASIL PENELITIAN}

Penelitian ini dilaksanakan di kelas I/A S1 PGSD Reguler pagi yang berlokasi di Kampus 2 Seganteng. Persiapan pelaksanaan penelitian dimulai sejak bulan Agustus tahun 2013, sedangkan pelaksanaan penelitian dilakukan mulai 21 Oktober 2013 sampai dengan 12 Nopember 2013. Penelitian ini adalah penelitian tindakan kelas, oleh karena itu, tahapan pelaksanaannya mengikuti tahapan: 
perencanaan, pelaksanaan tindakan, observasi, dan terakhir evalusi dan refleksi.

\section{a. Perencanaan}

Pada tahap perencanaan, peneliti melakukan kegiatan yang diperlukan untuk mendukung kelancaran pelaksanaan penelitian. Kegiatan yang dimaksud meliputi: koordinasi jadwal dengan tim peneliti, menyusun RPP yang berbasis realistik dalam kelompok kooperatif, menyusun lembar kerja mahasiswa (LKM) yang mendukung RPP, menyusun lembar observasi aktivitas mahasiswa dan dosen, dan menyusun soal evaluasi untuk tiap siklus penelitian. Pada akhir bulan Agustus, semua perangkat penelitian untuk siklus I telah siap digunakan.

\section{b. Pelaksanaan Tindakan}

Pada tahap ini, peneliti melaksanakan pembelajaran yang berbasis realistik dalam kelompok kooperatif. Kegiatan pembelajaran dilakukan dalam dua siklus, dengan masingmasing siklus terdiri atas dua pertemuan. Pada siklus I, materi yang dibahas adalah persamaan linear satu variabel pada pertemuan pertama, dan dilanjutkan dengan materi pertidaksamaan linear pada pertemuan kedua. Setelah pertemuan kedua, kegiatan siklus I ditutup dengan melakukan evaluasi. Tahapan serupa juga dilakukan dalam pelaksanaan siklus II. Hanya saja, selain materi siklus II berbeda dengan siklus I, tindakan pembelajaran yang dilaksanakan pada siklus II juga berbeda dengan siklus I. Materi siklus II adalah persmaan kuadrat pada pertemuan pertama dan pertidaksamaan kuadrat untuk pertemuan kedua. Sedangkan tindakan pada siklus II merupakan tindakan perbaikan yang perlu dilakukan setelah melihat hasil refleksi siklus I.

Secara umum, pelaksanaan pembelajaran yang dilakukan peneliti adalah sebagai berikut. Setelah memastikan bahwa mahasiswa siap untuk melaksanakan proses belajar, dosen model menyampaikan gambaran umum materi, konsep prasyarat yang dibutuhkan, kemudian meminta mahasiswa duduk dalam kelompok masing-masing. Selanjutnya dosen membagikan LKM pada setiap kelompok untuk didiskusikan. Setelah 40 menit berdiskusi, perwakilan kelompok mahasiswa diminta untuk mempresentasikan hasil diskusi kelompoknya. Kelompok lain diberikan kesempatan untuk menanggapi.

Poin pentingnya dalah pada bentuk dan struktur LKM yang dikerjakan mahasiswa. LKM berisi sajian masalah kontekstual, masalah yang berkaitan dengan kehidupan keseharian mahasiswa, sehingga setiap kelompok dapat/boleh menyelesaikan permasalahan tersebut dengan cara mereka masing-masing. Tahap matematika formalnya dibentuk setelahnya.

\section{c. Observasi}

Kegiatan pengamatan dilakukan pada aktivitas dosen dan mahasiswa. Terhadap aktivitas dosen, komponen pengamatan meliputi sejauh mana prinsip-prinsip pembelajaran matematika realistik diterapkan dalam proses pembelajaran. Sedangkan pengamatan aktivitas mahasiswa bertujuan unutk mengetahui kesesuaian antara tindakan yang dilakukan dosen dengan aktivitas mahasiswa dalam kerangka pembelajaran matematika realistik. Komponen lengkap pengamatan dapat dilihat pada lampiran. Berikut ini disajikan hasil observasi terhadap aktivitas dosen dan mahasiswa.

Tabel 1. Hasil Observasi Aktivitas Dosen

\begin{tabular}{lcccc}
\hline \multirow{2}{*}{ Komponen Utama } & \multicolumn{4}{c}{ Keterlaksanaan persiklus (\%) } \\
& I/1 & I/2 & II/1 & II/2 \\
\hline Penggunaan kontek Nyata & 75 & 100 & 100 & 100 \\
Penggunaaan Model Matematis & 100 & 100 & 100 & 100 \\
Penggunaan Produksi dan Konstruksi Mahasiswa & 80 & 80 & 100 & 100 \\
Penggunaan Interaktivitas & 80 & 80 & 100 & 100 \\
Penggunaan Keterkaitan & 100 & 100 & 100 & 100 \\
\hline
\end{tabular}

Dari tabel di atas terlihat bahwa pada siklus I belum semua komponen dalam tahapan PMR terlaksana dengan baik. Sedangkan pada siklus II, setelah dilakukan perbaikan, semua komponen yang menjadi tahapan pembelajaran PMR sudah terlaksana. Demikian juga halnya dengan aktivitas belajar mahasiswa. Partisipasi 
mahasiswa pada siklus II lebih baik dari siklus

sebelumnya.

Tabel 2. Hasil Observasi Aktivitas Siswa

\begin{tabular}{lcccc}
\hline & \multicolumn{2}{c}{ Pertemuan ke-1 } & \multicolumn{2}{c}{ Pertemuan ke-2 } \\
Siklus/Pertemuan & Skor & Kategori & Skor & Kategori \\
\hline Siklus I & 46 & Tinggi & 47 & Tinggi \\
Siklus II & 54 & Sangat Tinggi & 59 & Sangat Tingi \\
\hline
\end{tabular}

\section{d. Evaluasi dan Refleksi}

Kegiatan evaluasi dilaksanakan pada akhir siklus I dan siklus II. Soal merupakan reprenstasi dari materi yang dibahas dalam pertemuan pertama dan pertemuan kedua pada tiap siklusnya. Rekapitulasi hasil evaluasi siklus I disajikan dalam tabel berikut ini.

Tabel 3. Hasil Evaluasi Siklus I

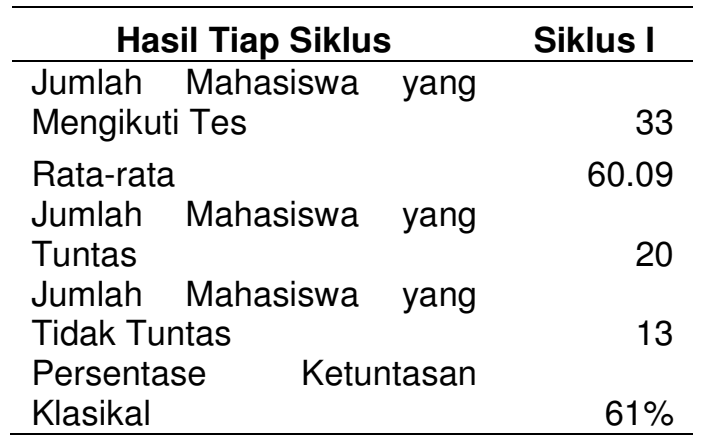

Dari 33 peserta yang mengikuti tes, 20 orang tuntas sedangkan sisanya belum tuntas. Sehingga persentase ketuntasan klasikal hanya mencapai $61 \%$. Masih di bawah standar yang ditetapkan peneliti. Oleh Karen itu penelitian perlu dilanjutkan ke siklus berikutnya.

Setelah peneliti mengetahui hasil observasi dan evaluasi siklus I, peneliti melakukan refleksi atas tindakan yang sudah dilakukan, sehingga diketahui penyebab masih rendahnya capaian hasil belajar mahasiswa. Berdasarkan hasil refleksi diketahui bahwa beberapa hal berikut menjadi penyebab utama masih rendahnya ketuntasan belajar mahasiswa.

1. Mahasiswa masih cenderung bekerja sendiri meskipun mereka dalam kelompok, sehingga sebagian mahsiswa hanya melihat teman kelompoknya yang bekerja.

2. Setiap kelompok hanya memperloeh 2 lembar LKM untuk kelompok dengan jumlah anggota 4 orang, sehingga sebagian anggota hanya melihat anggota lainnya yang mengerjakan LKM
3. Tipe masalah yang disajikan dalam LKM berisi kasus yang memungkinkan mahasiswa memahami matematika secara horizontal. Sedangkan kasus yang terkait matematika formalnya tidak diberikan pada LKM. Dampaknya mahsiswa memiliki pengalaman yang minim dalam menyelesaikan soal matematika secara formal.

4. Fokus kerja kelompok hanya untuk menyelesaikan LKM, sehingga ketika LKM sudah selesai, diskusi kelompok berhenti meskipun sebagian anggota kelompok belum memahami konsep yang didiskusikan. Durasi waktu diskusi kelompok jadi sedikit.

5. Sebagian besar mahasiswa masih sungkan untuk mengemukakan idenya saat diskusi kelompok maupaun ketika memberikan tanggapan saat presentasi klasikal dilakukan.

Mengacu pada hasil refleksi tersebut, diambil beberapa langkah perbaikan yang dianggap dapat mengatasi masalah yang terjadi. Langkah perbaikan tersebut adalah sebagai berikut.

1. Kelompok dibagi ulang. Pembagian ulang ini dilakukan dengan memperhatikan heterogenitas kemampuan berdasarkan hasil siklus I. Tujuan pembagian ulang ini adalah agar terjadi interaksi yang lebih padu antara setiap anggota dalam kelompok. Kemampuan yang heterogen memungkinkan mahasisiwa untuk beriteraksi secara partisipatif.

2. Waktu berdiskusi kelompok diperpanjang. Hal ini dilakukan untuk memastikan semua anggota kelompok memahami hasil kerja kelompok.

3. Jumlah kelompok yang melakukan presentasi ditambah. Penambhan ini dengan memperhatikan prinsip pemerataan.

4. Setiap anggota kelompok memperoleh lembar LKM. Pada siklus I, setiap kelompok 
hanya memperoleh 2 lembar LKM. Sedangkan pada siklus II, setiap peserta memperoleh LKM, sehingga setiap anggota merasa mempunyai tanggung jawab yang sama dalam menyelesaikan LKM.

5. Setelah presentasi, mahasiswa diberikan latihan soal secara mandiri. Tujuannya adalah untuk melatih mahasiswa mengerjakan matematika secara formal.

Setelah dilakukan perbaikan pada siklus II, partisipasi mahasiswa dalam belajar juga meningkat dari kategori tinggi pada siklus I menjadi sangat tinggi pada siklus II. Hasil belajar pada siklus II juga menunjukkan perubahan yang berarti. Ketuntasan klasikal yang hanya mencapai $61 \%$ pada siklus I, meningkat menjadi $88 \%$ pada siklus II. Berikut ini disajikan tabel rekapitulasi hasil belajar siklus II.

Tabel 4. Hasil Belajar Siklus II

\begin{tabular}{lr}
\hline \multicolumn{1}{c}{ Hasil Tiap Siklus } & Siklus II \\
\hline Jumlah Mahasiswa yang Mengikuti & 33 \\
Tes & 80.45 \\
Rata-rata & 29 \\
Jumlah Mahasiswa yang Tuntas & \\
Jumlah Mahasiswa yang Tidak & 4 \\
Tuntas & $88 \%$ \\
Persentase Ketuntasan Klasikal & \\
\hline
\end{tabular}

Dari tabel di atas terlihat bahwa jumlah mahasiswa yang tuntas 29 orang dari 33 orang mahasiswa yang mengikuti tes. Sedangkan 4 orang yang belum tuntas, diberikan penguatan pada pertemuan berikutnnya.

\section{B. PEMBAHASAN}

Penelitian tindakan kelas yang dilaksanakan di kelas I/A S1 PGSD Reguler pagi telah memberikan gambaran bahwa pembelajaran matematika dengan menerapkan pembelajaran berbasis realistik membantu mahasiswa dalam mempelajari matematika dengan lebih baik. Hal ini ditunjukkan dengan perolehan hasil belajar mahasiswa yang sangat baik setelah penerapan pembelajaran berbsais realistik pada materi persamaan dan pertidaksamaan. Partisipasi mahasiswa dalam belajar juga sangat baik, sehingga pembelajaran yang dilaksanakan membantu mahasiswa dalam memahami konsep matematika secara lebaih baik. Secara singkat, perbaikan kualitas dan hasil belajar mahasiswa dapat dilihat tabel berikut.
Tabel 5.Ringkasan Hasil Penelitian

\begin{tabular}{lcl}
\hline $\begin{array}{l}\text { Siklus/ } \\
\text { Hasil }\end{array}$ & $\begin{array}{l}\text { Aktivitas } \\
\text { Belajar } \\
\text { Mahasiswa }\end{array}$ & $\begin{array}{l}\text { Hasil } \\
\text { Belajar } \\
\text { Mahasiswa }\end{array}$ \\
\hline Siklus I & Tinggi & $61 \%$ tuntas \\
Siklus II & Sangat Tinggi & $88 \%$ tuntas \\
\hline
\end{tabular}

Penerapan pendekatan matematika realistik memang tidak secara otomatis langsung dapat memperbaiki hasil belajar mahasiswa. Ketuntasan klasikal $88 \%$ tercapai pada siklus II setelah dilakukan perbaikan pembelajaran pada siklus I. Kondisi ini tentu sangat mudah dipahami karena pembelajaran konsep matematika yang berangkat dari konstruksi masalah kontekstual tidak biasa dialami mahasiswa. Pada umumnya, pembelajaran matematika yang mereka jalani selalu berangkat dari konsep umum yang dijelaskan secara langsung. Mahasiswa berusaha memahami penjelasan, kemudian dilanjutkan dengan latihan soal. Tentu saja, tidak ada salah benar dalam konteks ini.

Sedangkan pembelajaran matematika relaistik memberikan kesempatan kepada mahasiswa untuk menyelesaikan masalah keseharian mereka dengan cara mereka sendiri. Penyelesaian masalah keseharian tersebut menjadi tahap pertama dalam pembelajaran. Bukan penjelasan konsep umum yang dilakukan secara klasikal. Selanjutnya, dari inetraksi yang dilakukan mahasiswa dan dengan bantuan dosen, mahasiswa akan sampai pada konsep matematika formal. Pembelajaran langsung berangkat dari konsep umum kemudian latihan penerapan konsep dalam konteks nyata, sementara matematika realistik berangkat dari arah sebaliknya. Konsep matematika dibangun melalui penyelesaian masalah kontekstual. Disitulah letak perbedaan utama antara pembelajaran matematika realistik dengan pembelajaran langsung.

Perbedaan pendekatan itulah yang menjadi penyebab bahwa penerapan pendekatan matematika realistik tidak secara otomatis langsung dapat merubah hasil belajar mahasiswa. Mahasiswa perlu pembiasaan dari hanya mendengarkan, memahami, kemudian latihan/bekerja, menjadi bekerja dulu, kemudian konsep terbentuk kemudian. Itulah sebabnya pada siklus I, hasil belajar mahasiswa hanya mencapai ketuntasan klasikal dibawah standar yang ditetapkan. Namun setelah dilakukan perbaikan pada pembelajaran siklus II, hasil 
belajar mahasiswa menjadi jauh lebih baik. Pada siklus II ketuntasan klasikal mencapai $88 \%$, jauh melebihi capaian ketuntasan klasikal pada siklus I yang hanya $61 \%$.

Penerapan pembelajaran matematika realistik juga memberikan kesempatan pada mahasiswa untuk melakukan eksplorasi konsep secara lebih utuh. Bekerja dengan masalah kontekstual, berinteraksi dengan dosen untuk menjembatani konsep, memberikan kesempatan untuk mengemukakan gagasan dan bekerja dengan cara mereka sendiri, terjadi interaksi mutualistis antar sesama mahasiswa, dan dengan memafaatkan keterkaitan antar konsep yang sudah dimiliki, sangat membantu mahasiswa dalam memahami konsep persamaan dengan aktivitas yang tinggi. Kelima tahapan tersebut sebagaimana dinyatakan Gravemeijer [4], menjadikan pembelajaran matematika dengan menggunakan pendekatan matematika realistik lebih mudah dipahami mahasiswa.

Fondasi paling dasar dari konsep PMR adalah menganggap matematika sebagai aktivitas manusia. Matematika harus berhubungan dengan realitas dan pembelajarannya harus berkaitan dengan pengalaman keseharian siswa. Belajar matematika adalah serangkaian proses untuk menemukan sendiri konsep-konsep matematika berdasarkan pengetahuan informal yang dimiliki siswa. Matematika disajikan bukan sebagai barang jadi yang dapat dipindahkan oleh guru ke dalam fikiran siswa. Aktivitas inilah yang oleh Freudenthal disebut sebagai Matematisasi [5]. Lebih jauh, hasil belajar matematika yang ditunjukkan mahasiswa S1 PGSD Kelas I/A juga mengkonfirmasi pentingya praktek pembelajaran berbasis realistik. Nilai mid semester mahasiswa menunjukkan hasil yang jauh lebih baik, dimana $68.4 \%$ mahasiswa memperoleh nilai $A$ dan $B$, dan $84.2 \%$ memperoleh nilai A, B, dan C. Tentu saja hasil ini sangat berbeda dan hasil pembelajaran pada tahun-tahun sebelumnya.

\section{KESIMPULAN DAN SARAN \\ A. Kesimpulan}

Berdsarkan hasil dan pembahasan di atas, beberapa hal yang dapat disimpulkan terkait penelitian ini adalah.

1. Pembelajaran Matematika Dasar Konsep Persaman dan Pertidaksamaan dengan menerapkan prinsip matematika realistik telah mampu memberikan pemahaman matematika yang lebih baik.
2. Semangat, partsisipasi dan respon mahasiswa dalam belajar matematika dengan menerapakn pembelajaran matematika realistik juga sangat baik.

\section{B. Saran}

Beberapa hal yang perlu menjadi rekomendasi dari hasil pelaksanaan penelitian ini adalah sebagai berikut.

1. Saran penelitian. Selain materi persamaan, beberapa materi matematika yang relaitif dianggap rumit oleh mahasiswa adalah materi geometri dan trigonometri. Kiranya penting untuk melakukan penelitian lanjutan pada topik-topik tersebut.

2. Saran tindakan. Hasil penelitian ini menunjukkan bahwa memang penerapan prinsip matematika realistik cocok dengan pembelajaran matematika. Oleh karena itu, terhadap dosen pengampu matakuliah matematika dan juga mahasiswa S1 PGSD sebagai guru matematika kelak, hendaknya menerapkan pembelajaran matematika yang berbasis realitik.

\section{DAFTAR PUSTAKA}

[1] Yuwono, I. 2001. RME dan Hasil Implementasinya di SMP. Makalah dalam Seminar Nasional "Realistic Mathematics Education" tanggal 24 Februari 2001 di Universitas Negeri Surabaya.

[2] Azmi, Syahrul, 2008. Penerapan Pembelajaran Matematika Realistik Untuk Membangun Pemahaman Siswa Tentang Konsep Pecahan Di Kelas IV SDN 2 Penedagandor Kabupaten Lombok Timur-NTB.

[3] Wardani, I.G.A.K., dkk, 2003. penelitian Tindakan Kelas. Jakarta : Pusat Penerbitan Universitas Terbuka.

[4] Gravemeijer, K.P.E., 1994. Develoving Realistic Mathematics Education. Freudenthal Institute, Utrecht.

[5] Hapipi, 2011. Pendidikan Matematika Realistik (PMR) sebagai Basis Pembelajaran Matematika, Jurnal Beta Jurusan Tadris Matematika IAIN Mataram Volume IV Nomor 01 Mei 2011. 